\title{
What the Regions Can Do to Overcome Stagnation and Rekindle Significant Socioeconomic Growth ${ }^{1}$
}

\author{
A. G. Aganbegyan* \\ Russian Presidential Academy of National Economy and Public Administration, Moscow, 119571 Russia \\ *e-mail:aganbegyan@ranepa.ru \\ Received April 8, 2020; revised April 25, 2020; accepted April 25, 2020
}

\begin{abstract}
The article discusses the crucial need to rekindle socioeconomic growth in Russia. It shows that the main directions on this path are financial boosting of investment in fixed assets and, to a greater extent, human capital. The state should put emphasis on technological re-equipping of the entire national economy, modern infrastructure, accelerated housing and social construction, and poverty alleviation. Mobilization of investment in fixed assets and knowledge economy is considered the main driver of socioeconomic development in regions and overcoming the present economic and social inequality. The potential advantages of investment lending, issuance of regional loans, and local budgets optimization are analyzed in detail. The article considers the opportunities regions have in improving the well-being of the population. Among the proposed measures are raising of the minimum wage, insurance in shared financing of housing construction, an adequate system of social benefits based on monitoring of needy families, and expansion of loans issued for education. The set of measures proposed by the author is supplemented by a set of necessary corrective measures in the face of serious risks involved in continuation of the COVID-19 pandemic and oil crisis. The article stresses a particular role of financial and monetary authorities in supporting business and the public.
\end{abstract}

Keywords: Russian regions, stagnation, economic growth, human capital, well-being, knowledge economy, financial investment incentives, regional budgets and programs, COVID-19 pandemic, oil shocks

DOI: $10.1134 / \mathrm{S} 2079970520030016$

\section{REKINDLING OF SOCIOECONOMIC GROWTH AS AN IMMEDIATE AND VITALLY IMPORTANT TASK FOR RUSSIA}

Russia's socioeconomic system has been stagnant since 2013. In these seven years, two (2015 and 2016) were years of recession. According to experts, this stagnation will last at least another two to three years.

Not only the Russian economy as a whole is stagnant. If we analyze the activities of each of the 85 federal subjects, then there are only about 10 regions exhibiting slight socioeconomic growth. In the vast majority, this growth is unsustainable, averaging 2$3 \%$ annually and dropping to zero in some years.

It would be a mistake to think that only the central government has real leverage to resume socioeconomic growth. To a greater or lesser extent, each region could achieve socioeconomic growth independently, despite stagnation in Russia as a whole, which is relevant to advanced regions. Take, e.g., Belgorod oblast. Its GRP increased by $3 \%$ in 2013; by 2.8 in 2014; by 3.0 in 2015; by 3.4 in 2016; by 3.7 in 2017; and by 3.5 in 2018 . Thus, within six years, growth in

\footnotetext{
${ }^{1}$ The article was updated by the author in 2020 for publication in Regional Research of Russia.
}

production amounted to more than $21 \%$, while in Russia as a whole, only $2.6 \%$, or $0.4 \%$ per year.

Of course, $3 \%$ growth is not enough for Russia for the future, since the economies of developing countries increase annually by an average of $4-5 \%$. Should such a low pace maintain, Indonesia with its huge population of $264 \mathrm{mln}$ people will soon surpass Russia. In addition, with $3 \%$ growth in the foreseeable future (within 15-20 years), we are unlikely to be among the developed countries of the world. This is especially true for the most important social indicators for which the gap is the largest. The author believes that the desired significant pace for Russia's socioeconomic development is $5-6 \%$ annually.

And here it is not so much the quantitative growth indicators that are critical, but qualititative. On the one hand, the goal is to increase industrial performance and technology to exceptional levels. On the other, economy expansion rates should focus on the growth of people's well-being in all segments of society, with the predominant formation of a large middle class.

Let us consider the national macroeconomic background, which substantially determines the situation in Russian regions. 
Among the negative trends pulling the country's economy down are capital flight, obsolescence of fixed assets, declining solvent demand, negative demographic changes, decelerated and sometimes negative state budget dynamics due to a decrease in oil and gas export revenues, etc. Radical measures are needed to overcome stagnation and these trends. It would be necessary to change economic and social policies, passing to financial boosting. This requirement primarily applies to investment in fixed assets, the knowledge economy, and its main componenthuman capital. In [2], we wrote about the need to strengthen financial support for growth. Accelerated, say, $10 \%$ growth of investments and injections should be directed at technological re-equipping of the national economy as a whole, new modern infrastructure, and accelerated housing and social construction.

Another fundamental characteristic of quality of growth is its subordination to the task of improving the well-being of the entire population with the priority of improving health and increasing the expected healthy lifetime. National priorities, goals, and models of economic development are considered in [1], as well as in [12].

To resume economic growth, appropriate conditions must be created. The key here is to reduce interest rates for investment loans to 3-5\%. The state should introduce strong incentives for investment and economic growth; these include project financing, tax breaks for technological upgrades, export of finished products with high value added, effective import substitution, etc. It is also necessary to carry out major institutional (structural) reforms to privatize property and develop competitiveness. Regions must be transferred to a system of self-sufficiency, self-financing, and self-government. The government needs to carry out several reforms: involving taxes, pension funding, and healthcare expenses. Housing and communal services should be privatized, and a number of other transformations should be carried out. In my opinion, it is advisable, following the example of China, Japan, and postwar France, to resume national economic planning in Russia taking into account new market conditions. A five-year 2021-2025 plan should be drawn up to implement the Decree of the President of the Russian Federation of May 7, 2018. Such a decision is especially important for the development of regions inside the national economic space. Interesting ideas in regional strategy and forecasting in the Russian Federation were formulated in studies by renowned regionalists $[6,9]$.

Thanks to these considerable measures, socioeconomic growth would pick up significantly in three to four years. Of course, these measures are not in the competence of the regional authorities. However, regions also have considerable leverage to overcome stagnation and to achieve social and economic development. Both the necessary resources and best prac- tices of regional management are available for this [11]. The main thing is to find drivers and growth points for regional development (which are available even in the most depressed regions) and deftly activate them.

\section{MOBILIZATION OF INVESTMENT IN FIXED CAPITAL AND KNOWLEDGE ECONOMY AS MAIN DRIVERS OF SOCIOECONOMIC DEVELOPMENT IN REGIONS}

Any significant socioeconomic growth in modern conditions can hardly be achieved in a region and maintained for several years without an 8-10\% increase in investment in fixed assets and human capital. The share of these investment and contributions to GDP has been proved to be in strong correlation with economic growth rates.

In developed countries, the share of investment in GDP is on average $21 \%$, while the share of investment in the knowledge economy is more than $30 \%$. This provides them with high-quality socioeconomic growth, on average 1.5-2\% annually. In developing countries, the share of investment in fixed assets in GDP is $30-35 \%$, while the share of investment in the knowledge economy is about $20 \%$. Therefore, they increase their GDP by an average of $4-5 \%$ per year, though to a large extent due to the development of traditional industries and with significant use of extensive factors. At present, China, with the share of investment in fixed assets at the level of $45 \%$ and investment in the knowledge economy at the level of $22 \%$, provides growth in the postcrisis period in the amount of $6.5-7 \%$ per year.

Today, Russia's share of investment in fixed assets is at $17 \%$ (in 2018, this figure amounted to RUB 17.6 tln against the GDP of RUB $103.6 \mathrm{bln}$ ), and the total share of the knowledge economy sector in GDP is at 14\% (RUB 15 bln). With such ratios, over the past six years, in conditions of declining investments and injections, we are naturally developing the economy at a level of $0-1 \%$ on average per year. It is necessary, though, to take into account the negative impact of sanctions, on the one hand, and the decline in oil prices, on the other.

To pass to socioeconomic growth, it is necessary to raise the rate of investment and contributions to GDP. There are no alternatives if we want to achieve significant long-term development of the Russian economy and social sphere. The above completely applies to the vast majority of regions, since their shares of investment and contributions to GRP are extremely low.

Why are such significant investment and contributions needed for economic growth? Investment are necessary:

-To provide retrofit for existing manufacturing plants. At least two-thirds of sectors have outdated fixed assets, especially machinery and equipment. In 
Russia, $23 \%$ of machinery and equipment are operating beyond their depreciation period; they were scheduled for scrap a long time ago. Depreciation of fixed assets has already exceeded $50 \%$ and is further increasing.

-To double, then triple Russia's undeveloped high-tech industries: electronics, pharmaceuticals, modern instrumentation, the aerospace industry, nuclear engineering, the upper echelons of the chemical industry, production of modern synthetic materials, etc.

- To create a modern transport and logistics infrastructure and make the transition to mass construction of two-lane highways, high-speed railways, and large logistics centers.

-To ensure the growth of housing and communal and social construction at least 1.7 times by 2025 and 2.5 times by 2030 . The goal is to bring provision of comfortable housing to $30 \mathrm{~m}^{2}$ per capita.

-To develop of all sectors of the knowledge economy.

The need for innovation-oriented investment in new technologies and infrastructure has been pointed out by many authors $[4,5,15]$.

Growth of the knowledge economy by $8-10 \%$ should be aimed at increasing the share of expenditures in certain sectors of GDP by 2025 :

- R\&D, from 1.2 to $3 \%$;

- education, from 4 to $7 \%$;

- information technology, from 3.5 to $10 \%$;

- biotechnology and healthcare, from 5 to $8 \%$.

These indicators can also serve as certain guidelines for regions.

What can be the sources of such significant investment in fixed assets and knowledge economy for regions? The main additional source of these funds may be investment loans. Not everyone realizes that Russia's main "money bag" is bank assets, which amounted to RUB 97.9 tln by April 2020. They more than double the total amount of state funds-the consolidated budget plus extrabudgetary state funds (pension, health, and social funds), where only RUB 40 tln are concentrated.

Today, the volume of investment lending in the country is negligible. Less than $1 \%$ of bank assets are used for investment loans from Russian banks to domestic enterprises. In general, all types of investment lending, including foreign lending, make up only $8 \%$ of Russian investments. In developed countries, this share reaches $30-50 \%$, and in developing countries it reaches $20-25 \%$ with twice as much contribution to GDP. Irrecoverable investments predominate here, often used extremely inefficiently, for various other purposes, including due to changing conditions. There is no obligation to return these funds, therefore no such strict liability as with investment lending. And this is without even mentioning corruption schemes.
In contrast, an investment loan is repayable. An issuing commercial bank has its interest in redemption. Otherwise it will lose the money it does not possess if the loan is not fully returned. If these funds are provided to a commercial bank from the Central Bank of the Russian Federation, or VEB.RF (Russian State Development Corporation), let alone international banks, the responsibility for their nonrepayment will likely fall to criminal prosecution, lead to bankruptcy of the bank, deprivation of its license, etc.

In addition, an investment loan cannot be issued without a detailed business plan and validation of the payback period, which is verified by the bank. Experienced bank employees are also involved in negotiations on purchasing equipment to finance the borrowing enterprise. Then the bank usually transfers the money directly to the manufacturer of this equipment after its delivery. The bank also takes part in negotiations with builders if they are constructing facilities for new enterprise capacities; it also transfers money directly to builders when they perform an agreed-upon set of jobs. Therefore, these funds can hardly be used inappropriately. To a large extent, they simply do not ever show in the enterprise's accounts. It is extremely important that experts from banks join the difficult task of technological retrofit of enterprises. The bank can hire experts not only in Russia, but also abroad, from among reliable specialists in this field. Therefore, an investment loan is much more effective than nonrepayable investments. It is also advisable to conduct all additional funds allocated for investment through the credit system in case of recoupment of the project.

At present, taking out an investment loan is unprofitable: it is extremely expensive and requires a minimum $10 \%$ annual interest rate. The profitability of most enterprises is below $10 \%$, so they cannot afford such a loan. Moreover, it is usually issued for a period of no more than three years, aside from companies being afraid to incur debts for a more extended period and be obliged to pay an exorbitantly high and disadvantageous return.

Proceeding from all this, in order to switch to investment lending as the main source of additional investment in fixed assets on a massive scale, an investment loan needs to be provided: at $5 \%$ per annum for technological retrofit at existing manufacturing plants with a payback period of 5-7 years; at $4 \%$ to create new capacities in high-tech industries with a payback period of 10-12 years; at 3\% for the creation of a modern transport infrastructure with a payback of $20-25$ years.

The Central Bank has recently lowered its key rate and has already brought it up to $5.5 \%$. It intends to reduce it further, at least in the near future, given the risks of the continuing COVID-19 pandemic and oil crisis. Regions could already today subsidize part of the interest rate when using investment loans from Russian commercial banks. These are relatively small 
funds. To take out a RUB 10 bln loan at $5 \%$ per annum interest rate, a company should only invest RUB 500 $\mathrm{mln}$ to reduce interest rates from 10 to 5\%. Probably, a gubernatorial investment loan guarantee will also be required.

Where should such funds to regional budgets come from? The problem of financial support for regions is extremely acute. Imbalances in center-periphery financial flows and the inefficiency of interbudgetary transfers are well known. Studies by many authors are devoted to this $[8,10,13]$. The necessary funds can be obtained if part of the budget items related to investments in the national economy, instead of irrecoverable financing, is transferred to a credit basis at mutually beneficial rates. The released funds are more than sufficient to cofinance interest rates on other investment projects. Experience shows that enterprises immediately line up for an investment loan on technological upgrades, even if it is partially issued at $5 \%$ per annum or less. Such loans, as is known, are provided by the Industrial Development Fund under the Ministry of Industry and Trade of Russia. More than 300 enterprises are queued up there. Thousands more enterprises simply do not submit applications, because it is difficult to break through. It also offers simpler and more favorable conditions than in this fund. Therefore, such loans will be in demand.

Another source of funds is associated with the possibility of regional administrations attracting additional financial resources. Budgets can be made moderately unprofitable with a deficit of $1-3 \%$ of GRP, the extent of safety and disinflation. The expenses then will exceed revenues, and these additional funds can be used to finance economic growth through investment loans. This will ensure their unconditional return: they will not be eaten up. Regional bonds may be issued under this deficit.

In addition, regional authorities themselves can take out loans, and at more favorable rates than enterprises. These can be budget loans, VEB loans, and loans from large commercial banks. They will be given to the region at lower rates than to a single enterprise. These investment loans should also be used for costeffective projects, especially those being implemented as part of a public-private partnership, which must be fully developed. Against budget volumes, such indebtedness would be secure at 50-60\%. Meanwhile, many regions take pride in their revenues exceeding expenses and them operating with a surplus. Such a region, simultaneously, may have no money for SMEs' costeffective projects stagnant due to lack of funds. The region does not attract workers, since few new capacities are introduced, etc.

It is time to realize that surplus means wasting money that depreciates from meaningless necrosis. Let's look at civilized countries: they all have adverse budgets. These are the most successful countries-the United States and Germany. And what are their debts?
External debts of European states make up an average of $86 \%$. The Russian Federation has a foreign debt of $3 \%$; it allegedly does not need money. It is enough for Russia to have a $17 \%$ share of investment in GDP and to be stagnating instead of moving forward with much larger investments, which it could quickly cover by taking out USD 50-100 bln. A perfectly safe situation with Russia's extremely small domestic and foreign debts. China has foreign and domestic debts of $257 \%$ of GDP, and the country is developing very successfully. In Japan, these debts are more than $200 \%$; the United States has its public debt alone at $120 \%$. And Russia has domestic and foreign debts of $15 \%$ in total. Even if we account for the debt shared among all our enterprises and organizations, plus government debt, this is only $29 \%$ of GDP, while the international secure norm is $60 \%$ of GDP. In Russia, 20 mln poor people have incomes below the subsistence minimum; $7 \%$ of workers have a salary equal to the subsistence level. Housing construction is vastly underfunded and fell from $85 \mathrm{mln} \mathrm{m}^{2}$ in 2015 to $75 \mathrm{mln} \mathrm{m}^{2}$ in 2018. But the crucial underfunded aspect is socioeconomic growth.

However, in truth, we are sitting on a chest of gold. The Central Bank announced that as of April 2020, the country's gold reserves in gold and foreign exchange reserves exceeded USD $120 \mathrm{bln}$, and all reserves, USD $563 \mathrm{bln}$. In the past 15 years, we have never touched USD $300 \mathrm{bln}$. When RUB 600 bln was suddenly required, the government increased VAT by $2 \%$. In relation to the mentioned reserves, this is an insignificant amount given with a stroke of the pen by G. Gref, head of Sberbank, where only RUB 13 tln have been deposited by citizens. The authorities raised inflation to $5.5 \%$ and reduced the incomes of tens of millions of people. For the sixth year, real disposable incomes have been declining, and we are living with a budget surplus, fabulous reserves, five times greater than in the largest countries of Europe surpassing Russia in terms of their economies. But how pleasant it is to sit on a chest of gold, which every year is worth USD 20-25 bln. And this is not RUB 600 bln, but more than RUB 1.2 tln.

It is not necessary to imitate such departmentalfiscal behavior. It is necessary to look at advanced countries and how and owing to what are they developing. Try developing a company without credit, without debt. You'll be marking time. At best, you'll move forward in small steps. The same goes for regions. It is not necessary to fear feasible loans or debts that are economically substantiated. It is only necessary to spend them efficiently on a gross basis and not to distribute them right and left irrecoverably. We sometimes do this, but we don't achieve the proper effect.

Take the development program for the Far East. The program was adopted in 2013. Six years in, the state granted unprecedented benefits and invested 
huge amounts of money. The program includes the construction of 1500 enterprises, for which the government has started allocating RUB 3.88 tln. However, the results are low. GRP hardly grew at all, and the pace is lower than that for Russia as a whole, despite the fact that in other regions there are no such benefits and investments. Agriculture is simply degrading. For six years, meat production decreased by $20 \%$, milk production by $10 \%$, and grain volume by 2.5 times. In recent years, the volume of housing construction has decreased: almost two times less housing per 1000 inhabitants than the average in other regions. But everything is aimed at rapid development of the Far East. What is this 'priority development' exactly? There is a large population outflow from the region, and the standard of living is not increasing. Why? Because money is used irrecoverably, inefficiently. After the establishment high benefits for priority development territories created in the Far East and for which vast funds were spent, investment suddenly, while falling before, soared by $17 \%$ in 2017 . It seemed that with such an increase in investment, there should be at least some economic results. But no: The GRP of the Far East in 2018 grew by $1.8 \%$, and in Russia, with an increase in investment of $4 \%$, it grew by $2.3 \%$. There is no need to take an example from this; it is necessary to act efficiently, to use money predominantly on a recoverable basis.

The source of additional funds may be privatization of a number of state-owned enterprises and organizations. A significant number of these enterprises are subordinate to regions or municipalities and do not perform any state functions but are purely commercial. A few years ago, I was involved in the development strategy of Kostroma oblast. I was surprised to see that the state owned a completely obsolete logging association. It almost does not use industrial complexes that have mechanized production, successfully used in private structures. Why does the state need this primitive, semi-unprofitable logging? What state tasks does it resolve? The regional administration owns a shopping center in Kostroma. Once it was a monument of pre-revolutionary architecture. Now it is a dilapidated building with a leaky roof, but it is state property, nonetheless. Where is value for the state? Leased out poor premises. Another state-owned enterprise is a greenhouse for tomatoes and cucumbers sold to the public. And what is of the state here? Why is it not private? We could go on. Each region has something similar.

A positive example is Moscow Government. It sold to private business, for good money (trillions of rubles), such apparently profitable organizations as the Bank of Moscow, beautiful Vnukovo Airport, and many other facilities. The funds were invested in development of the city.

It is extremely beneficial for regions if they are ready to engage in serious administrative work, create special economic zones (SEZs), priority development areas, industrial parks, and technological development zones, as well as support other similar structures specially created by the government. This encourages more profitable innovative business, the development of import substitution, and export production. Large benefits are granted on profits, on taxes not only on profits, but also on property, land, customs, and administrative benefits, and much more.

But how badly all of it is used. Efficient zones can be counted on one's fingers. There is Yelabuga-a small SEZ that has concentrated the backbone of enterprises whose production volume has already exceeded RUB 150 bln and continues to increase. A technological development zone without benefits was created near the Novosibirsk Akademgorodok [16]. Its income is more than RUB 20 bln and growing rapidly. The Lipetsk SEZ has long paid for itself. In the newly created SEZ of Moscow oblast in Protvino, 11 enterprises are already operating and 14 are being built. Although only a few years have passed, production has already begun. It is necessary to use to the fullest extent all the advantages that the federal government provides.

And many regions are "sleeping," sluggish, in no hurry to join a good new business-even the most successful of them. Take our best, in our opinion, Russian region-the Republic of Tatarstan. There are already 80 perinatal centers in the country, and in Tatarstan, where there are $4 \mathrm{mln}$ people and high birth rates, the first perinatal center has only recently opened. Therefore, infant mortality is quite high there compared to other Volga regions. Nearby, in the poorly financed Chuvash Republic, it is 1.5 times lower.

Exceptional cardiac centers were created everywhere in the country as the main component of the Health program. The government spared no money on them. But Kostroma oblast missed the mark; its cardiac center is incapable of anything. And in order to put a simple pacemaker, patients are forced to drive $4 \mathrm{~h}$ to Ivanovo. The largest efficient federal cancer center operates in Rostov-on-Don. Nearby are other major cities. And yet they have no modern positron emission tomography (PET) center that can detect cancer metastases visible by no other means. There were many opportunities to create a PET center, but nothing was done. Although both private and state-owned companies were eager to organize such a center in Rostov-on-Don, even spend their funds; they only requested free space. And there are dozens of such examples.

Extremely important is the problem of financial support for housing construction, in particular, competition in the credit market (for more details, see [14]). Additional funds can be obtained via the issuance of special bond loans, beneficial both for regions and the population. For example, they can be used to finance housing or purchase cars. A bond loan is 
announced, and those who want to purchase a home purchase bonds from this loan. It gives a small income a year, but as soon as a certain percentage of the price of an apartment has accumulated, the administration guarantees the choice of an apartment, e.g., with a $30 \%$ discount on the price and a mortgage loan at a low interest rate. At the expense of what? Because the money that people gave three years ago, two years ago, a year ago, went toward housing construction. This money went to specific private housing companies with which the region's administration concluded an agreement: we provide you additional money for housing from a bond loan a year or two years before it is commissioned, and you give an apartment for these borrowers at a discount. Everyone naturally agrees as it dramatically increases housing demand. It is possible to calculate how much this is beneficial to the builders. And the administration loses nothing; it acts as a skilled mediator.

This is no less beneficial for the population, for a significant part of which the cost of new housing has risen over the past two years by as much as $30 \%$ : by $15-20 \%$ because of the need to buy ready-made housing, and not at a discount, as before, when it started to sell after the completion of foundation works, and by $15 \%$ due to many construction companies that financed housing with funds from the participation interest having left the market. It is the same with cars. Indeed, the population in Russia has accumulated RUB 30 tln in bank deposits alone. And according to experts, Russians has from USD 700 to 1000 bln in foreign bank accounts. The use of at least $3 \%$ of this amount affords great opportunities for additional financing for housing construction and car production.

\section{OPPORTUNITIES FOR REGIONS TO IMPROVE THE WELL-BEING OF THE POPULATION}

Improving the well-being of the population is not just a goal of economic development. And this does not only entail their prosperity. It is important to understand that a person is the main productive force, and work efficiency depends on caring for this main productive force. Precisely human capital, human knowledge, and skills increasingly determine socioeconomic growth.

Human life has a definite price, which has not been established in our country. If a person dies, e.g., in a plane crash, the family is paid RUB $2 \mathrm{mln}$ for his life. A recent Superjet accident was the first instant when the families received RUB 5 mln each; this is already progress. Rosstat calculated that saving a person's life provides RUB $4.4 \mathrm{mln}$ in the national economy. By my calculations, this figure is underestimated at least threefold. From my viewpoint, a human life in Russia costs about RUB $10-12 \mathrm{mln}$. It is no coincidence that mortal accidents on international flights (including aircrafts that belong to very underdeveloped countries, such as India) are compensated with at least USD 150000 , or approximately RUB $10 \mathrm{mln}$. In the United States, the official price of a citizen's life is more than USD $1 \mathrm{mln}$. Production of GDP per capita according to purchasing power parity in Russia is about three times less than in the US, and at the market rate, five to six times. So, if we take the cost of living of a US citizen as a criterion, then the cost of living of one Russian should be about USD 200000, or RUB $15 \mathrm{mln}$.

Therefore, various measures to increase well-being in certain areas are often recouped. And this payback is sometimes higher than the return on investment in fixed assets. For example, saving 100 lives due to improved treatment of cardiovascular diseases will give annual savings, even if calculated according to Rosstat, of RUB $440 \mathrm{mln}$. We intend to reduce the mortality of the working-age population by 100000 people per year. These 100000 people will yield RUB 400 bln a year in the annual contribution to the country's economy. After person's life is saved, that person lives, as a rule, for about $10-15$ years, if this amount of life is preserved during his working age. Actual aspects of Russian healthcare are touched upon in our study [15].

An increase in housing construction has a huge effect in the national economy. Housing construction provides a high additional effect. It entails the creation of infrastructure, the founding of communal networks, the construction of social amenities necessary for residents, the formation of new cash flows for the sale of housing and payment for utilities, the additional purchase of goods when acquiring new housing, etc. In general, it is believed that about $20 \%$ of GDP growth depends on housing construction, naturally if it has significant values (approximately $0.7-1 \mathrm{~m}^{2}$ per capita per year). It is this amount of housing that must annually be commission in the future.

I have not even broached the fact that investment in education has a huge additional effect, albeit difficult to calculate. Studies by foreign scientists show that in different countries from one- to two-thirds of the sources of economic growth are directly or indirectly associated with improving education: the role of man in the modern production of goods and services is that important. Indeed, the share of intellectual services in creating GDP has increased dramatically. The services of doctors, teachers, IT specialists, and many others almost entirely depend on their qualifications and not on the building in which they work, sometimes not even on the equipment they use.

Therefore, the increase in well-being should be comprehensive, rolling into the economic effect of this increase. And the biggest economic effect is provided by healthcare, education, and housing. In order to rationally channel funds and influence the processes of improving well-being, it is necessary first to know people's needs and requirements. To do this, it 
is necessary to conduct various surveys related to certain events, meet people, experience their interests. Moreover, it should be borne in mind that the population is multilayered; it has different social groups, people with different interests. They should be approached differently. It is one thing for young people, another for older members of society, a third for women with small children, fourth for breadwinning men of working age. We need different approaches to residents of large cities, urban-type settlements, and rural areas. Thus, a multifaceted social policy must be worked out, that is very balanced and cautious.

The worst problem in Russia is the large number of poor people. According to estimates, $30 \%$ of Russians live worse than people of this category lived in Soviet times, and $20 \%$ live much better, sharply pulling up the average. For the $10 \%$ of low-paid workers, wage is RUB 12000; for the $10 \%$ of high-paid workers, almost RUB 156000. The average wage is about RUB 45000. However, between 45000 and 12000 , the difference is 33000 , and between 45000 and 156000 , it is 111000 . This is a huge gap. It is clear that RUB 111000 pulls the average up three times more strongly. Therefore, not 50 , but almost $70 \%$ of employees receive below the arithmetic average. The median wage is about $70 \%$ of the average. That is, with an average of RUB 45000 , the median will be a little more than RUB 30000; 50\% will receiver greater or less than this value. And there is also the mode number, the most common wage in the same interval. If, say, we calculate what percentage of workers receive from RUB 10000 to 15000 , from 15000 to 20000 , and from 20000 to 25000 , then the majority will be workers who receive from RUB 20000 to 25000 . This will be the tallest column, and the curve that passes through the top of these columns will initially rise steeply to a peak, then slowly descend. On this descent, at first there will be the median, then the arithmetic mean.

The distribution of per capita income also looks the same. However, if the difference between poor and rich in terms of wages is 13 times, then the difference between rich and poor in $10 \%$ groups is 15.5 times. This is blatant social inequality, the most painful aspect in our lives. In Japan, the difference in per capita incomes is not 15.5 times, but 5 times. In socioeconomically oriented European countries, this is 6 times; in Germany, 8 times; in Europe as a whole, 10 times; but by far not 15. As a matter of fact, in Soviet Russia in the early 1980s, this difference was 3 times, and in 1990, during the period of deficit, speculation, and rampant disorganized markets, it increased to 4 times.

We must always consider this difference and by all means try to reduce it to a reasonable extent. Regions have a lever for this, raise the minimum wage. First of all, raising the minimum wage applies to private business, since there are more employees than in the public sector. Forcing private business to share an increas- ingly large share of profits with employees is in line with social justice. And what is happening in our country is far from justice. Say, in 2015, the monetary growth of wages amounted to only $4.6 \%$, while in previous years it increased by $9-12 \%$ per year. Inflation, in contrast, in previous years was at a level of 7-9\%, and in 2015, it jumped to $15.5 \%$. Therefore, in 2015, real wages fell by $9.5 \%$. Yes, it was a recession, but GDP fell by less than $3 \%$. There was no reason for real wages to fall by almost $10 \%$. The most interesting thing is that at this time, the profit of all enterprises and organizations in the national economy of Russia, net of loss, i.e., the financial result, increased by $93 \%$ due to rising industrial prices. Who admitted that the wage fund grew by several percent, and the total profit, by 1.8 times? What kind of social policy is this; what kind of distribution of funds between entrepreneurs and workers? This speaks to the absence of real social policy!

In no case should the regional authorities allow such distortions. Therefore, it is necessary to monitor well-being indicators all the time, to constantly interview people, and meet their desires and needs. People's interests should not be neglected, as has been done recently. The retirement age has been increased, which, according to polls, was opposed by $95 \%$ of the country's total population. Against the will of the people, VAT was increased. Against the will of the people, housing has become $15 \%$ (so far) more expensive in the absence of the $15 \%$ discount on it. For those who bought residential property at the first stages of construction with a $15-20 \%$ discount, it went up by a third. It has risen in price for $100 \%$ of the population, so that there are no deceived equity holders (this is $0.38 \%$ of those who received housing, of shared financing for housing, owing to which housing prices became cheaper, and more was constructed). Meanwhile, solving the problems of these interest holders required pennies to spend: the authorities needed to introduce insurance, as was done during bankruptcy of banks, where the percentage of lost deposits is much higher than the percentage of defrauded interest holders.

Raising the minimum wage in regions (which most regions practically do not take advantage) could significantly reduce the poverty level and encourage private business to pay large wages. What else can reduce the outflow of workers from many regions, and at the same time increase regional budget taxes? Local authorities have such leverage: the introduction of various social benefits to the needy, to large families, pensioners, people with disabilities, and orphans. To do this, you need to have reasonable data on poor families. Criteria should be developed and enacted fairly, not formally. One of the main tasks of each regional administration is to form a middle class. It should become the pillar of power, the pillar of the country, as is the case in other countries. Our middle class is strat- 
ified into rich and poor and is extremely unstable. The situation here needs to change substantially.

The priority of regional social policy is the health of the population, the expected healthy lifetime. The Decree of the President of the Russian Federation of May 7, 2018, sets the goal of bringing this indicator to 67 years by 2024 . Today, it is at a level of 60 years. For this, there should first be a reduction in the mortality rate of working-age people; second, there should be a reduction in mortality from cardiovascular diseases, then from external causes; the most difficult is to reduce the mortality rate from cancer. "The ray of light in the kingdom of darkness" is a reduction in infant mortality, according to which in 2019 we are likely to reach the first set indicator for 2024 from the Decree of the President of the Russian Federation. In 2018, this indicator was 5.1 per 1000 births. The president's goal for 2024 is 4.5. In the first quarter of 2019, a result of 4.3 was achieved on average in Russia. Most regions annually reduce it significantly.

The second priority that needs to be monitored is household private consumption. We are talking about the consumption of food, industrial goods, cost structure, etc.

The third priority is reduction in social inequality. Moreover, the inequalities are not only in income and consumption, which can be analyzed in some way, but also in the distribution of housing and healthcare, especially with the deterioration of medical services in rural areas. Inequality in education is growing, which increasingly worries the population. Regions could make it so that banks give out loans with a relatively low interest rate $(3-4 \%)$ to everyone who receives professional paid education, from a skilled worker or programmer, to master degree, postgraduate study, doctoral studies, and extended education like MBA, DBA degrees, and so on. Issues of economic and social inequality in the regions are addressed by N.V. Zubarevich in [7].

Ensuring a decent standard of living is a multifaceted task. It includes environmental problems, life safety, high mortality from external causes, including road injuries, suicides, murders, deaths from fires, floods, etc. It includes the problem of familiarizing oneself with culture, physical education and sports, and much, much more. It is impossible to cover everything. However, local authorities should take a broad view on the issues and monitor the main aspects of a person's life and main groups of the population, immediately responding to substantiated claims and sensible proposals. Each regional administration should create a situational center that would daily monitor and process various types of information on all aspects of the region's life. The best such center I have seen is in the city of Kyzylorda in Kazakhstan. Owing, among other things, to its work, the development strategy elaborated there has been carried out successfully, and Kyzylorda oblast from among the most backward regions of Kazakhstan has advanced to a middle position.

\section{FIGHTING THE CORONAVIRUS WITHOUT DESTROYING THE ECONOMY}

In 2020, two new problems were imposed on Russian stagnation and recession: the COVID-19 pandemic and catastrophic decline in oil and gas prices, which have to be fought on two fronts. Therefore, in addition to the measures noted above (which, of course, should be corrected under the new conditions), new economic, financial, and social maneuvers aimed at supporting business and human capital are necessary.

\section{Supporting the Economy in an Epidemic}

The coronavirus came to Russia later than it did to other countries. The first person in Moscow infected with coronavirus was detected on March 2; the operational headquarters for the fight against infection was created in February. Fortunately, adequate measures were taken on time, one might even say ahead of schedule. Therefore, our epidemic is spreading more slowly than in other countries. Over the past 50 days, by April 24, the number of cases amounted to about 69000 people, less than 500 per $1 \mathrm{mln}$ inhabitants. In large countries of Europe and in the United States, the number of cases per $1 \mathrm{mln}$ is from 2000 to 3000 people. The most significant difference between Russia is low mortality. Only a little more than 600 people died during this time, which is $0.9 \%$ of the number of cases, while in the countries of Western Europe and the United States, this is $3-5 \%$.

According to the data for mid-April 2020, the following situation has developed in Russia with spreading of the coronavirus. A unique feature of the COVID-19 epidemic in Russia is its concentration in Moscow, which accounts for about $60 \%$ of all patients. In Moscow, there are about 2000 cases per $1 \mathrm{mln}$ people. In second place is the Komi Republic, with more than 400 people; there are much fewer in Moscow oblast, St. Petersburg, and several other regions. In more than 30 regions, no one has yet died from the coronavirus. In more than 40 regions, up to 3 people have died. More than half of the regions have an incidence of less than 50 people per $1 \mathrm{mln}$. More than $60 \mathrm{mln}$ people live in these regions and about $40 \%$ of GDP is produced. With the observance of strict selfprotection measures in regions with low morbidity, it is necessary not to reduce, but to increase the economy if possible. Meanwhile, according to the latest data, up to $25 \mathrm{mln}$ people in the country are not working; $76 \%$ of the Russian population are self-isolating at home; and one-third of enterprises and organizations sent their workers on forced leave without pay, which, in our opinion, is completely unacceptable. In any 
case, they all need to be given at least unemployment benefits.

In my opinion, the government has underestimated the depth of the crisis from such downtime and is not taking appropriate measures to support the economy. Accordingly, the allocated financial resources are insufficient. Small and medium businesses are supported by a small amount of funds. At first, RUB 300 bln were allocated, then RUB 1.4 th for anticrisis measures. After each speech by the President and the Prime Minister of the Russian Federation with specific proposals, modest measures are also being taken on benefits and preferences. For example, measures to provide a mortgage loan at a rate of $6.5 \%$, as well as payment of small amounts, e.g., RUB 23 bln to air carriers facing upcoming losses of hundreds of billions of rubles.

Meanwhile, we still face no less difficult times than during the crisis of 2008-2009. Then, at the initiative of Prime Minister V.V. Putin, large funds for anticrisis measures were mobilized from the fourth quarter of 2008. The total amount spent to overcome this crisis amounted to $10.9 \%$ of GDP (in relation to the size of GDP in 2019, it is RUB $12 \mathrm{tln}$ ). An amount of USD 211 bln was spent from foreign exchange reserves alone, including to prevent collapse of the ruble.

Taking into account future investments, according to the Minister of Finance A. Siluanov, only $2.8 \%$ of GDP will be directed at preventing the socioeconomic consequences of the coronavirus epidemic, while in the United Kingdom $20 \%$ will be spent on these purposes, $14 \%$ in France, and $10.4 \%$ in the United States. Per capita, we will spend almost ten times less than large developed countries. A program to support the economy and incomes of citizens affected by the coronavirus epidemic has not yet been made public and apparently has not been drawn up. This program's expenses should amount, in my opinion, to RUB 10 thn, possibly 15 thn to prevent the worst consequences of a recession with a $3-5 \%$ reduction in GDP, an increase in unemployment by 3-5 mln people, a reduction in disposable income by $5-10 \%$, and an increase in poverty by 1.5 times.

\section{The Priority is to Compensate for Loss of Income and Prevent an Increase in Poverty}

We need global measures to maintain incomes, which during the period of stagnation in 2013-2019 decreased by $7.5 \%$, and to reduce the number of poor, which increased during the stagnation period by $5 \mathrm{mln}$ people. This is compounded by the forced deterioration of living conditions from the new crisis. When part of the economy is down, the number of unemployed in Russia may double. The current level of unemployment benefits is completely inadequate for families to survive this period. It should be increased to at least twice the amount of the minimum subsistence level.

In order to compensate for loss of income during the period of stagnation and a new crisis in 20202021 , it is advisable, in my opinion, to first raise the minimum wage from RUB 12100 to 20000 per month. This is more effective than a lump-sum payment of benefits to all families in need. Many private enterprises and joint-stock companies can finance the increase of this minimum at the expense of their accumulated funds. In recent years, they have significantly increased the amount in domestic banks accounts - up to RUB $30 \mathrm{tln}$. They have sent a lot of funds to offshore and foreign accounts, where they still have hundreds of billions of dollars. And raising the minimum wage will cost them only RUB 5 th. As for state employees and some enterprises, primarily small and mediumsized businesses, here the state will have to help, and this will require about RUB 3 tln.

\section{The Coronavirus Pandemic and Oil Shocks}

A feature of the current crisis situation in Russia in the context of the COVID-19 pandemic is that these processes occur against the backdrop of a catastrophic decline in oil prices. In the best case, the price of Urals will rise to USD $40-45$ per barrel by 2022 . We should forget pre-crisis oil prices of USD 60-65 per barrel, as well as the previous volumes of oil production due to declining demand. The share of oil revenues in the formation of the federal budget, which used to be 40$50 \%$ and decreased to $35 \%$, will probably decrease to $20-25 \%$. We are forcibly "getting off the oil and gas needle." The price of natural gas for the year fell from USD 200 to almost 100 for the export of $1000 \mathrm{~m}^{3}$ gas with declining export.

In these conditions, one must learn to live in a new way and shape exports based on the sale of finished products with high value added, as well as export services. This is difficult, but possible, as the experience of India in the 1990s shows, where unprecedented measures were taken to stimulate the export of finished products.

The main conclusion, which is true for the current situation, is that we need to look for new sources of additional financing while increasing the efficiency of its use. The assets of Russian banks are the main promising source.

\section{The Central Bank's Special Role in Overcoming the Deepening Recession}

In almost all countries that have experienced recession from the coronavirus, central banks have played the largest role in financial assistance to overcome it. Whereas the United State budget, e.g., allocated USD 2 tln for these purposes, the Federal Reserve System announced aid measures with a total cost of USD 6 tln, three times as much. The foregoing applies 
to Germany, France, Italy, the United Kingdom, and Spain, where interest-free loans guaranteed by the state, or loans with a minimum interest rate, are the main means of helping enterprises and organizations, as well as citizens. The European Central Bank, for its part, has allocated EUR 1 th for these purposes.

These are difficult times. As noted above, the assets of Russian banks are the country's main "money bag." Therefore, the Central Bank should be turned into a bank for socioeconomic development that must work in the closest cooperation with the government. The first steps, I hope, have been taken here, but so far, it has allocated the minimum amount of money. In addition, for unknown reasons, interest on deposits will be taxed.

By normalizing oil prices and having to reduce oil production and the volume of export supplies, it is necessary to strengthen the ruble, which depreciated by about $30 \%$ against the dollar. Meanwhile, Russia's total foreign debt is approaching USD 500 bln and requires about USD $110 \mathrm{bln}$ in annual payments for servicing. At such a ruble exchange rate, the situation is ruining the country. In addition, import is extremely expensive, but without it many chemical and machinery enterprises will halt, along with the supply of many consumer goods, etc. A stronger ruble will create conditions to lower inflation. And an increase in prices, of course, reduces real wages and pensions and depreciates social assistance. Already today we need to think about anti-inflationary measures, but not the ones that the Central Bank commonly uses to maintain liquidity, restrict the issuance of loans, and raise the interest rate. Conversely, in order to exit the crisis, it is necessary to lower the interest rate, following the example of almost all other countries, and cross over to the mass issuance of interest-free loans or loans at a minimum interest rate of $3-5 \%$. It is good that the Central Bank reduced the key rate on April 24, 2020, to $5.5 \%$.

It is time to streamline the entire system of lending to the population, setting a maximum limit of no higher than $8 \%$ of the rate under more favorable conditions for their repayment, reducing the amount of fines and allowances, insuring these deposits, etc. In the nearest future, it would be necessary, partially at the expense of banks, and partially at the expense of the state, to ease the credit burden for low-income population and prevent mass bankruptcy of families, as is happening now.

In conclusion, I reiterate: radical measures and trillions of rubles are the means we really need to overcome the crisis in Russia and win-on the one front, the coronavirus, and on the other one, the oil and gas crisis, recession, and stagnation.

\section{CONFLICT OF INTEREST}

The author declares that he has no conflicts of interest.

\section{REFERENCES}

1. Aganbegyan, A.G., $O$ prioritetakh sotsial'noi politiki (Priorities of Social Policy), Moscow: Delo, 2018.

2. Aganbegyan, A.G., Finansy, byudzhet i banki $v$ novoi Rossii (Finances, Budget, and Banks in New Russia), Moscow: Delo, 2019.

3. Aganbegyan, A.G., Demografiya $i$ zdravookhranenie Rossii na rubezhe vekov (Demography and Healthcare of Russia at the Turn of the Centuries), Moscow: Delo, 2019.

4. Borshchevskii, G.A., Creating institutional conditions for attracting investment to infrastructure: the experience of Russian regions, Vopr. Ekon., 2019, no. 2, pp. 134-157.

5. Dvoretskaya, A.E., The role of credit-financial institutions in the development of the infrastructure of the national innovation system, Bankovskoe Delo, 2018, no. 8, pp. 19-27.

6. Zubarevich, N.V., The strategy of spatial development: priorities and means, Vopr. Ekon., 2019, no. 1, pp. 135146.

7. Zubarevich, N.V., Disparity of regions and large cities of Russia: what has changed in the 2010's? Obshch. Nauki Sovrem., 2019, no. 4, pp. 57-70.

8. Klimanov, V.V., Eremina, D.A., and Mikhailova, A.A., The balance of financial flows between the Center and regions in Russian Federation, EKO, 2018, no. 9, pp. 51-62.

9. Klimanov, V.V., Budaeva, K.V., Safina, A.I., and Yagovkina, V.A., Regional'noe strategirovanie, prognozirovanie i programmirovanie v Rossiiskoi Federatsii (Regional Strategic Planning, Forecasting, and Programming in Russian Federation), Moscow: IROF, 2019.

10. Klimanov, V.V., Deryugin, A.N., Mikhailova, A.A., and Yagovkina, V.A., Byudzhetnyi federalizm: finansovoe uchastie regionov $v$ dostizhenii natsional'nykh tselei razvitiya (Budgetary Federalism: Financial Participation of the Regions to Achieve National Targets of Development), Moscow: Delo, 2019.

11. Leksin, V.N. and Shvetsov, A.N., Reformy i regiony: sistemnyi analiz protsessov reformirovaniya regional'noi ekonomiki, stanovleniya federalizma $i$ mestnogo samoupravleniya (Reforms and Regions: System Analysis of Reformation of Regional Economics, Development of Federalism, and Local Self-Governance), Moscow: Lenand, 2012.

12. Mau, V.A., National goals and model of economic growth: new in the socioeconomic policy of Russia in 2018-2019, Vopr. Ekon., 2019, no. 3, pp. 5-28.

13. Mikhailova, A.A., Klimanov, V.V., and Safina, A.I., The impact of interbudgetary transfers on economic growth and the structure of the regional economics, $\mathrm{Vo}$ pr. Ekon., 2018, no. 1, pp. 91-103.

14. Mishura, A.V., Bekareva, S.V., and Mel'tenisova, E.N., How does lack of competition restrain housing lending in Russian regional markets? Vopr. Ekon., 2020, no. 4, pp. 107-128.

15. Natsional'nyi doklad "Vysokotekhnologichnyi biznes v regionakh Rossii" (National Report "High-Tech Business in Russian Regions”), no. 2, Zemtsov, S.P., Ed., Moscow: Ross. Akad. Narodnogo Khoz. Gos. Sluzh., 2019.

16. Seliverstov, V.E., Akademgorodok 2.0 megaproject: are dreams coming true? Reg. Res. Russ., 2020, vol. 10, no. 1 , pp. 107-116. 